\title{
COMMITMENT OF LOCAL GOVERNMENT IN PROVIDING LEGAL AID FOR THE POOR SOCIETY $\Omega$
}

\author{
Saru Arifin \\ Faculty of Law, Universitas Negeri Semarang \\ E-mail: saruarifin@mail.unnes.ac.id
}

\begin{abstract}
The birth of the Legal Aid Act in the year of 2011 had strengthened the right of legal assistance for the poor in resolving legal issues that arrise. In the Act, Local Goverment is given the authority to provide legal assistance. This study uses socio-juridical method that aims to analyze the commitment of the local government of Badung regency, Bali, as one of the region with the highest revenue in In-donesia, in providing legal assistance. These results indicate that high local revenue of Badung re-gency, Bali are not positively correlated with the commitment to provide the legal assistance to the poor. This is indicated by the absence of a Local Regulation on legal aid and no funds were allocated to help the poor who need legal help. In addition, in the implementation of legal aid in Badung there are two main obstacles that the lack of regulation of legal aid and the constraints the letter to re-sidents from outside the area.
\end{abstract}

Keywords: legal aid, poor people, justice, legal aid institute

\begin{abstract}
Abstrak
Lahirnya UU Bantuan Hukum tahun 2011 memperkuat hak bantuan hukum bagi masyarakat miskin dalam menyelesaikan masalah hukum yang dihadapinya. Dalam UU Bantuan Hukum Pemerintah Daerah diberikan kewenangan memberikan bantuan hukum. Penelitian ini menggunakan metode yuridissosiologis yang bertujuan untuk menganalisis komitmen Pemerintah Daerah Kabupaten Badung, Bali, sebagai salah satu Daerah yang memiliki Peghasilan Asli Daerah tertinggi di Indonesia, dalam memberikan bantuan hukum. Hasil penelitian ini menunjukkan bahwa tingginya Pendapatan Asli Dae-rah Kabupaten Badung Bali tidak berkorelasi positif dengan komitmen bantuan hukum kepada masyarakat tidak mampu yang menghadapi masalah hukum. Hal ini ditunjukkan dengan tidak adanya Peraturan Daerah tentang bantuan hukum dan juga tidak ada dana yang dialokasikan untuk membantu masyarakat tidak mampu yang memerlukan bantuan hukum. Selain itu, dalam pelaksanaan bantuan hukum di Badung terdapat dua kendala utama yakni tidak adanya Perda bantuan hukum dan kendala surat keterangan miskin bagi penduduk dari luar daerah.
\end{abstract}

Kata kunci: bantuan hukum, masyarakat miskin, keadilan, lembaga bantuan hukum

\section{Introduction}

The commitment of Indonesia in creating a democratic state based on law ${ }^{1}$ as affirmed in Article 1 Constitution 1945 (UUD 1945) has striv-

$\Omega \quad$ This article is part of research funded by Pusjakum DPD $\mathrm{RI}$ in scheme of Kajian Jangka Panjang Kelompok Muda with Contract number of DN.070/07A/DPD/VII/2014. Thanks to Faculty of Law, Universitas Negeri Semarang for facilitating this research. Then, thanks to LBH Denpasar, Law Section Pemkab Badung Bali, Asosiasi Pendidikan Hukum Klinis Indonesia, and surely Researcher Team of Dewa Sudika Mangku, Ristina Yudhanti, and all assistants who help to run this research.

1 Suroto, “Macam-Macam Konsep Negara Hukum", Jurnal Konstitusi, Vol. I No. 1, November 2012, Jakarta: Mahkamah Konstitusi, page 119. ed to equip various legal instruments relating to the assertion of its existence. One of the effort taken to realize the constitutional rights of citizens is to provide justice access to obtain legal aid. ${ }^{2}$ It was known that the law, empirically much enjoyed by people who have the ability to pay for a lawyer or advocat. While the poor people, when they have the legal cases likely to surrender to circumstances. In such situations,

Nandang Sambas, "Pendekatan Kebijakan Formulasi Terhadap Undang-Undang Nomor 16 Tahun 2011 Tentang Bantuan Hukum". Jurnal Hukum Prioritas, Vol. 4 No. 2, 2014, Jakarta: Faculty of Law, Trisakti, page 2. 
they become victims from many legal processes that they do not "understand".

In the history of law practice in Indonesia, the efforts to provide legal assistance for free (pro bono), began in the 1960s era were marked by the establishment of the Legal Aid Institute (LBH) in Yogyakarta by Senior lawyer, Adnan Buyung Nasution. This institution created with the aim to provide legal assistance for free to people who have a legal problem, but does not have the ability to pay a lawyer to defend the rights and interests of those associated with the legal case that it faces.

The conditions according to Frank S Bloch ${ }^{3}$ is quite prevalent, especially in poor countrieswhere the access to justice can not be widely accepted by society. Bloch ${ }^{4}$ stated that:

"In many poorer countries, justice is inaccessible to a large number of people simply because they are unaware of laws and legal institutions, not to mention specific legal rights. In such situations, it is not just a question of having access to legal representation; access to justice initiatives must first address this lack of knowledge by bringing basic legal awareness or legal literacy to the general population".

Awaring those conditions, the Indonesian government has demonstrated its commitment to provide justice for poor people, which can only be felt by those who have money and power. Related to this thing, the study aims to analyze the implementation of Article 19 Law Number 16 Year 2011 concerning Legal Aid, which provides space for local governments to provide legal assistance. In this context, location takes place in Badung Bali as a case of study research. This location was selected on two

3 Frank S Bloch, "Access to Justice and the Global Clinical Movement", Journal of Law \& Policy, Vol. 28, 2011, Washington: Washington University, page 111; See also Scott L Cummings, "The Politics of Pro Bono." UCLA Law Review, Vol. 52. No. 1, 2004, California: UCLA School of Law, page 6; Rebecca L Sandefur, "Lawyers' Pro Bono Service and American-Style Civil Legal Assistance." Law \& Society Review, Vol. 41. No. 1, 2007, South America: John Wiley \& Sons publications, page 79; Macey, Jonathan R. "Mandatory Pro Bono: Comfort for the Poor or Welfare of the Rich." Cornell L. Rev. 77, 1991, New York: Cornell Law School, page 1115.

4 Loc.cit. considerations, which are: the legal case that occurs each year by Badung people is increasing. For example, based on data from the Central Bureau of Statistics, ${ }^{5}$ it shows that during the period of 2006-2010 occurred as many as 1,405 cases involving adult community groups, children and strangers. The situation is quite alarming, where case law is prevalent in all walks of life, including foreigners. ${ }^{6}$ It is not in spite of Bali as a tourist destination for foreign tourists. A number of legal cases are still being in Police hands and still untouched, mostly the poor people who do not have the financial ability to afford a lawyer.

Badung Regency Government is one of the local governments that have regional revenue which reached 2.2 Trillion and in the year 2014 increased significantly to around 3 Trillion over in its draft budget. In this connection, it is interesting to study more about the right accommodation of Badung people who have legal problems and was not able to get relief assistance of legal problems that they faced.

\section{Problems}

Based on the description of the background above the problems, the problem of research that formulated as follows: first, how committment of Bali Badung regency government in the provision of legal aid for the underprivileged; and second, what are the obstacles faced in the provision of legal aid for rich people who have legal problem in Badung.

\section{Research methods}

This type of research is a combination of juridical-normative and empiric, that examines the legal issues in a practical dimension, particularly related to the implementation of Law Number 16 Year 2011 and equipped with a review of the rule such as: Law, legislation, ministry laws, and regional regulations related to legal aid issues. ${ }^{7}$ Furthermore, the data collected, both from the field (primary data) and seconda-

BPS, 2012, Badung Dalam Angka, Badung: BPS, page 47. Ibid, page 150 .

Peter Mahmud Marzuki, 2005, Penelitian Hukum, Jakarta: Prenada Media, page 27. 
ry data obtained in the research literature, the rule of law, described scientific articles and linked systematically to answer the issues that have been formulated. The analysis quali-tative descriptive to produce a research conclusions and recommendations.

\section{Discussion}

\section{Badung Government Commitment in Providing Legal Aid for the Poor People}

The provisions in Article 19 Law Number

16 Year 2011 concerning Legal Aid is facultative, the word 'may' merely approve the local government in providing legal aid to the poor. This legal slit empirically a pretext for the Badung regency to argue that it is not an obligation for the local government to specifically create legislation or provide specific funding allocations for the poor to obtain legal aid.

The conditions according to Komang Budi Argana, ${ }^{8}$ is caused by consideration that the legal issues that occur in the community had a channel, namely the Ministry of Justice and Human Rights and Legal Aid Institutions. In addition, it was also learned the existence of Law Number 16 Year 2011 concerning Legal Aid. Nowadays, according to Komang due to Article 19 of the Law on Legal Aid is facultative, it is not the urgent obligation to be followed up in a regulation. But it is committed to further evaluate the benefits of the local regulation of legal aid seen from the priorities of service needs and development in Badung.

According to Komang Budi Argana, ${ }^{9} \mathrm{Ba}$ dung District Government does not provide special funds on legal aid to the poor. That is because local regulation (Perda) does not exist and is not imperative. Therefore, even Badung government has large budgeting, it focuses more on allocation of funds for infrastructure the development of tourism as a major source of revenue and also agriculture.
The fact is in line with Ni Luh Gede Yastini's view ${ }^{10}$ from Denpasar Legal Aid Institution (LBH) which states as follows:

"... Yes Indeed they do not commit, they are busy giving the target of political affairs, so the social fund that they always look for now to villages ... yes of course, now, in Bali, they focused more to develop the buildings that support the tourism, and does not interest in the construction of the people...its equally with Badung, although the local revenue (PAD) is large ..."

$\mathrm{Ni}$ Luh's statement is explicitly recognized by Head of Legal Section Bali and Human Rights, Komang Budi Argana ${ }^{11}$ that the economic structure of Badung Bali is highly dependent on the tourism sector, so it so vulnerable, such as in the Bali bombings. The case accord-ing to Komang caused incapability of local government, such as paying the salary.

The conditions according to Gede Pasek Suadika, Chairman of Indonesian House of Regional Representatives (DPD RI) ${ }^{12}$ indicates the anomaly to legal aid for poor people, whereas Badung regency is one of the richest in Indonesia. In 2014 the budget of Badung regency reach 2,8 Billion Rupiah with real local revenue (PAD) until 3,2 Billion Rupiah. The reality contrasts with other areas of the budget and the real local revenue (PAD) is low, such as Sinjai which has only amounted to 443 Million Rupiah real local revenue (PAD) but has a real commitment to legal aid to the issuance of Regulation Number 18 Year 2013 Bill concerning Legal Aid for the Poor.

Such conditions shows a juridical problem in interpreting the provisions of Article 19 Law Number 16 Year 2011 on Legal Assistance caused by the lack of coordination between the $\mathrm{Mi}$ nistry of Justice and Human Rights with the Ministry of Internal Affairs. However, there is an interesting precedent represented by the Regio-

\footnotetext{
Interview at LBH Denpasar, 19/11/2014.

Ibid.

12 DPD RI, FGD Tentang Pelaksanaan Bantuan Hukum Daerah: Refleksi atas UU Nomor 16 Tahun 2011 Tentang Bantuan Hukum, 18/11/2014, Jakarta: DPD RI
} 
nal Government of Central Java and Medan. ${ }^{13}$ For example, Local Government of Central Java has shown real commitment in implementing the provisions of Article 19 Law Number 16 Year 2011 concerning Legal Aid. The commitment is realized with the enactment of the Provincial Regulation Number 7 Year 2014 concerning Legal Aid for Poor People. This regulation was further suplemented by Central Java Governor Regulation Number 40 Year 2014 concerning Implementation Guidelines for Central Java Provincial Regulation Number 7 Year 2014 concerning Legal Aid For Poor People.

While the main source of finance is concerned on Central Java provincial budget (APB D), besides it is also possible to take funds from grants or voluntary donations or other funding sources are legitimate and are not binding (Article 21 Provincial Regulation). Technically, the legal aid funds by the Local Government of Central Java shall be submitted by the legal aid agencies to the Governor in the form of proposal.

The funding that is allocated toward the budget of the Legal Bureau which is granted each quarter to Legal Aid Providers with the conditions have been reported in writing and the document of the implementation of legal aid by legal aid providers is completed, with the amount of the budget is based on a calculation of the legal issues of litigation and non-litigation (Article 13 paragraph (1) and paragraph (3). The pattern is in the financial system are called patterns of reimbursement, which can be paid after the activity is completed.

The patterns that has been implemented by the local government of Central Java, can be predicted as a model of legal aid by the local government. This matter is caused by the juridical difficulty in collocating the legal aid fund in budget scheme of Badung Regency's Regional

13 Wirawan, Cynthia, Syafruddin Kalo, and Edi Yunara. "Implementasi Pemberian Bantuan Hukum Cuma-Cuma (Pro Bono Publico) dalam Perkara Pidana di Kota Medan Ditinjau Berdasarkan Undang-Undang No. 16 Tahun 2011 Tentang Bantuan Hukum (Studi di Lembaga Bantuan Hukum Medan)." Jurnal Mahupiki, Vol. 2. No.1. 2014, Medan: Faculty of Law, Universitas Sumatera Utara, page 20-22.
Government Budget (APBD), because there is no guidance from Ministry of Internal Affairs but it can be solved just like the statement from Komang Budi Argana.

The absence of real commitment in implementing legal aid for the poor with the excuse there is no normative obligation as mentioned above, but there is the allocation of legal aid to the citizens in general that is provided by the local government of Badung , Bali, that is special, concerning to the issues of trafficking. It is marked by the release of the Local Regulation Number 65 Year 2012 concerning the Establishment of the Prevention and Handling Duty Crime of Trafficking. The group in charge of the legal aid, structurally led by Assistant Secretary General Administration of Badung, in field of Cooperation and Legal Aid, the composition of which is cross-sectoral .

In Article 14 of Local Regulation Number 65 Year 2012 confirmed two main programs in relation to legal aid, namely: providing legal aid to those who are victims of trafficking. Thus, in this context, legal aid paradigm that is built is to provide protection to the victims of human trafficking. Furthermore, legal aid is also provided to the society in general in the context of prevention and treatment of human trafficking. In this context can be interpreted, that legal aid is carried out by the local government of $\mathrm{Ba}$ dung regency as a preventive action by means of legal awareness to the community at large.

The situation is contrary to the objective conditions of the legal cases that hit the poor in Badung. In general, legal cases that occur in the Badung regency of Bali of the period (20062010), can be grouped into two categories, namely: legal cases which are civil and legal cases that are criminal or offense. Both groups seen from the doers, involve various elements of society, all gender and society's groups based on age. ${ }^{14}$

Ironically, among several criminal cases or violations, the vast majority were cases of petty crime or crime "small fry" as the theft cases that incidentally committed by low class of

14 See also BPS Kabupaten Badung, 2011, Loc.cit. 
people. There are so many theft cases with the value of smaller items, which are often under the spotlight of the media, because the prosecution of the perpetrators to justice, getting enough attention from the public. Public considers that cases of 'small involving low class people "is really not fair, if that cases are only given the punishment by 5 (five) years as stipulated in Article 36 of Indonesian Criminal Code therefore it is not comparable with the value of the stolen goods. That cases has also weighed on the court, both in terms of budget and public perception of the court. Lightweight theft case was charged with improper use of Article 362 Indonesian Criminal Code, the criminal threat at most 5 (five) years. The case should be included in the category of misdemeanors (lichte misdrijven) which should more appropriately charged under Indonesian Criminal Code Article 364 that the criminal threat than 3 (three) months imprisonment or a fine of not more Rp.250,00 (two hundred fifty rupiah). ${ }^{15}$

In practice, the poor who tripped legal cases as explained above, many of them asked for help from the Legal Aid Denpasar Bali. ${ }^{16}$ By region of origin and the claimants who received legal aid from LBH Bali, during the period, 2013, approximately $43.71 \%$ were from Denpasar, Badung followed by $21 \%$. As for the year 2014 until September 2014, Denpasar position remains ranked number one and reached $37,84 \%$, fol-lowed by residents with ID cards from outside Bali, which reached $26.11 \%$. The complaint is generally done in two ways, namely by the complainant to come directly to the LBH Bali claimants were 112 in 2013 and 106 in 2014. While the complainants other way is by consulting over the phone as much as 21 rounder in 2013 and the 16 claimants in 2014. Furthermore, there is also a complainant or legal consultations via email, in 2013 a total of 18 complainants, and in 2014 dropped to four com-plaints.

As seen from the doers, during 2013 and 2014 mostly done by workers with the number

15 Wirawan, Cynthia, Syafruddin Kalo, and Edi Yunara. op. cit., page 15.

16 LBH Denpasar, 2014. Laporan Penanganan Kasus di LBH Bali Tahun 2014, Denpasar: LBH, page 2-3. of cases respectively 58 and 68 cases. The second position is occupied by the excursion reached 42 cases in 2013 and 17 cases in 2014. If it is observed, the data showed that the number of varieties of the criminal case that resulted in the jailing of the criminalists of the crime, most of the cases: gambling, kidnapping, murder, assault, theft, robbery, extortion, embezzlement, fraud, narcotics and psychotropic occupied the two highest position among the criminal cases .

This situation illustrates that the crimes formerly known in simple form, such as stealing, cheating, even killing, are usually done with simple way. As if someone wanted to kill someone else, they usually waited somewhere, and after you finished hitting or killing others, they immediately run away or report to the po-lice. However, those ways to commit the crime has been transformed. Crime today is no longer a simple form and does not stand alone. These crimes tend to be more in the form of crimes carried out at one time and the same place. Those crimes (mostly) are done by people who are under the poverty line. ${ }^{17}$ The modus is easily predicted, such as stealing to fulfill their needs of life and family, and they automatically were forced to commit the crime.

The data above shows that behind the greatness of Badung regency as a world class tourist destination, saved quite a lot of legal issues among the poor, whether committed by migrants and locals. ${ }^{18}$ This situation would have an impact on the obstruction of the rights of poor people to get access to justice. Yet according Yastini, public enthusiasm was unable to obtain legal aid is quite high, especially when Law Number 16 Year 2011 was enforced. Here the statements of the Director of Legal Aid Denpasar:

17 See Ummi Kalsum, "Tanggung Jawab Negara terhadap Bantuan Hukum Masyarakat Miskin", Jurnal Nanggroe, Vol. 1 No.1, 2012, Aceh: Faculty of Law, Universitas Malikussaleh, page 58; See also Todung Mulya Lubis, "Bantuan Hukum Struktural: Redistribusi Kekuasaan dan Partisipasi dari Bawah", Jurnal Prisma, $5^{\text {th }}$ Edition, 1981, Jakarta: LP3ES, page 51.

18 Interview with Director of LBH Denpasar Ni Luh Gede Yastini, 19/11/2014. 
"... actually quite helpful to this law, because ultimately a lot of people who initially feared to court, afraid looking for a lawyer when dealing with the law, with this Act they became bold to ask for legal aid to LBH when in court with a letter for the poor".

Constitutional awareness shown by the poor in Badung Bali to ask legal assistance to LBH Denpasar to solve their legal problems is inline with the views Soerjono Soekanto ${ }^{19}$ who asserts that the public awareness of factors are variables that significantly influence law enforcement. In this regard, the Law on Legal Aid will be executed properly when from among the people are not able to have consciously seek legal aid in legal cases that is experienced.

\section{Obstacle in Provision of Legal Aid for the Poor in Badung Bali}

Law on Legal Aid as the law in general, in its implementation in the field (law in action) is in contact with the various social dynamics in society. In this context, the law in its implementation experiences different responses and perceptions in society that affect the execution in achieving their intended goals (law in text).

According Soerjono Soekanto, ${ }^{20}$ core issues in law enforcement is actually located on the factors that influence it. These factors have the neutral meaning, so the positive or negative impacts laying on the factors that consist of: first, the law factors itself, second, law upholder factor itself, which is the parties that form it or even apply the law; third, means factor or facilities which support law enforcement; fourth, community factor, an environment where the law is applied; and fifth, cultural factor, as a result ot the work, creativity, and sense based on human initiative in social life.

Based on data collected from field, when observing from various supporting factors in the implementation of legal aid in Badung, based on the theoretical classification as presented by

19 Soerjono Soekanto, 1986. Faktor-Faktor yang Mempengaruhi Penegakan Hukum, Jakarta: Rajawali Press, page 3 .

20 Ibid, page 36.
Soekanto can be described as follows. First, local regulations that have no legal aid regulations. As described earlier, that the Badung regency of Bali do not have any Legal Aid regulation because it is considered by local district government is not legally required, so it is only done a limited coordination with legal aid providers institutions such as LBH Denpasar.

The condition empirically affects the unequal access to justice for the underprivileged who have a legal problem in Badung. Because, as indicated by previous data that the legal cases hit the underprivileged in Badung is quite high. While legal aid providers only done primarily by LBH Denpasar with various limitations of the Human Resources and funding. This was stated by $\mathrm{Ni}$ Luh Gede Yastini ${ }^{21}$ stating that it was hassles enough to serve legal aid because the funds provided by the Ministry of Law and Human Rights is not comparable with the need for legal assistance requested by the poor. Moreover, the distribution model is using the mechanism of distribution terms which is sometimes out of sync with the operational needs of each case, so it is quite often for LBH Denpasar to cover first. The condition stated by Sihombing $^{22}$ has been recognized by the Government to establish a norm in Article 19 Law Number 16 Year 2012 which encourages the involvement of local government in the funding of legal aid which is unlikely to be handled by its own Ministry of Law \& Human Rights (Kemenkum HAM). ${ }^{23}$

In a broader scale, although by Article 22 Law Number 13 Year 2003 concerning Advocate is obliged the advocate to provide free legal assistance, but for those who are beginners especially in the regions it is difficult to apply due to

21 Interview, 19/11/2014.

22 See Eka NAM Sihombing, "Mendorong Pembentukan Peraturan daerah Tentang Bantuan Hukum di Provinsi Sumatera Utara", Jurnal Rechts Vinding: Media Pembinaan Hukum Nasional, Vol. 2 No. 1, April 2013, Jakarta: BP$\mathrm{HN}$, page 90.

23 See Andry Rahman Arif, “Pelaksanaan Pemberian Bantuan Hukum Terhadap Terdakwa Yang Tidak Mampu Dalam Perkara Pidana di Kota Bandar Lampung”, Fiat Justisia Jurnal Ilmu Hukum, Vol. 9 No. 1. January-March 2015, Lampung: Faculty of Law, Universitas Lampung, page 105-106. 
limited funds for legal aid ${ }^{24}$. Even as a comparison, in India it is actually quite the opposite, Advocates need to be given an incentive to support their performance in law enforcement ${ }^{25}$.

Second, the administrative constraints population. As we know that the Bali has so many immigrants who make a living in Pulau Dewata. This situation is also characterized by numerous violations of the law by the public, especially people with low economic. Related to this, people who are not capable of dealing with legal issues, especially those who come from outside the region has a population administrative constraints when asked for legal assistance to LBH Denpasar.

According to Ni Luh Gede Yastini ${ }^{26}$, generally the presence of Law Number 16 Year 2011 concerning Legal Aid is giving a positive impact on the growing of people awareness that can not afford to seek legal assistance, either directly come to the LBH or through their family or by phone and email. More statement by $\mathrm{Ni}$ Luh:

"... Actually this law is quite helpful, because in the end a lot of people who initially afraid to come to court, afraid to look for a lawyer when dealing with the law, with this Law they became bold to ask for legal assistance to LBH when they come to court bring a letter for the poor. It is troublesome, Bali has many immigrants, they do not have a Bali's ID card or do not have an ID card because they do not have time to return home, it is troublesome... yesterday I was also in contact with friends from LBH Yogyakarta, they have same problem, to those who have ID cards outside Java, the local government did not want to spend the letter fot the poor, it was difficult, even though this

24 Siti Aminah, "Analisa Putusan Mahkamah Konstitusi No. 88/PUU-X/2012 Tentang Permohonan Pengujian UndangUndang Nomor 16 Tahun 2011 Tentang Bantuan Hukum", Jurnal Keadilan: Mempromosikan Hak Asasi Manusia dan Keadilan Sosial, 04 $4^{\text {th }}$ edition of 2014, Jakarta: Indonesia Legal Resources Center, page 65; Abdul Hakim Garuda Nusantara, "Bantuan Hukum dan Kemiskinan Struktural." Jurnal Prisma, $1^{\text {st }}$ edition, Year 1981, Jakarta: LP3ES, page 35 .

25 Jagdev, "Welfare Measure for Advocates", Journal of the Campus Law Centre, Vol. I, 2013, New Delhi: New Delhi Campus Law Center, page 6.

26 Ibid. person is poor, in the end these people are not covered by this law, because of trouble in finding this letter... it was so difficult, because it is the administrative requirements ...".

The administrative constraints population become the weaknesses of the Law of Legal Aid, so that the poor people who go abroad and have a legal issue be constrained to get legal assistance from the LBH Denpasar because his ID card is not from the area. ${ }^{27}$ This condition according to Joseph Saefuddin must be addressed immediately so it will not inhibit the rights of the poor to obtain legal assistance ${ }^{28}$ The situation is different with the results of Satriawan's study, et al, ${ }^{29}$ and also Hekki Purnama Setia's research ${ }^{30}$ which found that, the poor in Bandar Lampung ${ }^{31}$ and Samarinda who have legal problems tend to be submissive and did not want to seek legal assistance to the organization of legal aid providers. In this case, the ad-ministration of residence is not a factor but is a factor of the low awareness of community to seek legal assistance. ${ }^{32}$

\section{Conclusion}

The results of this study showed that the implementation of legal aid in Badung and Bali

27 See more comprehensive review about Legal Aid problems in Tata Wijayanta, "Study Bantuan Hukum Golongan Tidak Mampu dalam Perkara Perdata di Pengadilan Negeri Yogyakarta." Jurnal Mimbar Hukum, Vol. 24. No. 1, 2012, Yogyakarta: Faculty of Law UGM, 110.

28 Yusuf Saefudin, "Implementasi Bantuan Hukum bagi Rakyat Miskin di Jawa Tengah Berdasarkan Undang-Undang Nomor 16 Tahun 2011 tentang Bantuan Hukum". Jurnal Idea Hukum, No. 1 Vol. 1, March 2015, Purwokerto: Faculty of Law Universitas Jenderal Soedirman, page 71.

29 See Andan Adi Satriawan, Upik Hamidah, and Satria Prayoga, "Implementasi Bantuan Hukum Pada Masyarakat Miskin di Kota Bandar Lampung (Studi Di Lembaga Bantuan Hukum Bandar Lampung)", Jurnal HIMA HAN, Vol. 1 No. 2, 2014, Lampung: Faculty of Law, Universitas Lampung, page 8.

30 Hekki Purnama Setia, "Faktor-Faktor Yang Menjadi Kendala Dalam Pemberian Bantuan Hukum Secara Cuma-Cuma (Prodeo) Dalam Perkara Pidana di Pengadilan Negeri di Samarinda”. Jurnal Ilmu Hukum dan Sosial, Vol. 2 No. 1, 2014, Samarinda: Faculty of Law, Universitas Tujuh Belas Agustus, page 1.

31 See Andry Rahman Arif, op.cit., page 107.

32 See also Bq Ishariatym Wika Utari, "Bantuan Hukum Secara Cuma-Cuma Bagi Tersangka/Terdakwa Yang Tidak Mampu," Jurnal IUS, Vol. 2. No. 4 Year 2014, Mataram: Faculty of Law, Universitas Mataram, page 1012-113. 
in general as follows. First, The commitment of Badung local government, Bali has not provide legal aid to the poor yet, both in terms of regulation (Local Regulation) and also the allocation of funding budget in APBD. This is because in the perception of the local government in the provision of Article 19 Law Number 16 Year 2011 concerning Legal Aid is facultative nature. Based on that condition, local government do not feel having any obligation to provide legal aid for the poor. However, local governments have a possibility in the future, it will be prepared in accordance with the development priorities in Badung.

Second, the obstacles in the implementation of legal aid for the poor in the Badung regency of Bali generally lies in two things: the absence of local regulations that provide guarantee and legal certainty in the provision of legal aid for the poor; moreover, the factor of population administration is also an obstacle, especially for poor people from outside Badung area who had legal problems in that area could not take care of this letter from the local authorities, so they tend to be resigned to the situation.

\section{References}

Aminah, Siti. "Analisa Putusan Mahkamah Konstitusi No. 88/PUU-X/2012 Tentang Permohonan Pengujian Undang-Undang Nomor 16 Tahun 2011 Tentang Bantuan Hukum”. Jurnal Keadilan: Mempromosikan Hak Asasi Manusia dan Keadilan Sosial, 04 ${ }^{\text {th }}$ edition of 2014. Jakarta: Indonesia Legal Resources Center;

Arif, Andry Rahman. "Pelaksanaan Pemberian Bantuan Hukum Terhadap Terdakwa yang Tidak Mampu dalam Perkara Pidana di Kota Bandar Lampung". Fiat Justisia Jurnal Ilmu Hukum, Vol. 9 No. 1. January-March 2015. Lampung: Faculty of Law Universitas Lampung;

Bloch, Frank S. "Access to Justice and the Global Clinical Movement". Journal of Law \& Policy. Vol. 28. 2011. Washington: Washington University;

BPS. 2012. Badung Dalam Angka. Badung: BPS;
Cummings, Scott L. "The Politics of Pro Bono." UCLA Law Review. Vol. 52. No. 1. 2004. California: UCLA School of Law;

DPD RI. FGD Tentang Pelaksanaan Bantuan Hukum Daerah: Refleksi atas UU Nomor 16 Tahun 2011 Tentang Bantuan Hukum. 18/ 11/2014. Jakarta: DPD RI

Jagdev. "Welfare Measure for Advocates". Journal of the Campus Law Centre, Vol. I. 2013. New Delhi: New Delhi Campus Law Center;

Kalsum, Ummi. "Tanggung Jawab Negara terhadap Bantuan Hukum Masyarakat Miskin". Jurnal nanggroe, Vol. 1 No.1. 2012. Aceh: Faculty of Law. Universitas Malikussaleh;

LBH Denpasar, 2014. Laporan Penanganan Kasus di LBH Bali Tahun 2014. Denpasar: LBH;

Lubis, Todung Mulya. "Bantuan Hukum Struktural: Redistribusi Kekuasaan dan Partisipa-si dari Bawah". Jurnal Prisma, $5^{\text {th }}$ Edi-tion. 1981. Jakarta: LP3ES;

Macey, Jonathan R. "Mandatory Pro Bono: Comfort for the Poor or Welfare of the Rich." Cornell L. Rev. 77. 1991. New York: Cornell Law School;

Marzuki, Peter Mahmud. 2005. Penelitian Hukum. Jakarta: Prenada Media;

Nusantara, Abdul Hakim Garuda. "Bantuan Hukum dan Kemiskinan Struktural." Jurnal Prisma, 1st edition. 1981. Jakarta: LP3ES;

Saefudin, Yusuf. “Implementasi Bantuan Hukum bagi Rakyat Miskin di Jawa Tengah Berdasarkan Undang-Undang Nomor 16 Tahun 2011 tentang Bantuan Hukum". Jurnal Idea Hukum, No. 1 Vol. 1. March 2015. Purwokerto: Faculty of Law Universitas Jenderal Soedirman;

Sambas, Nandang. "Pendekatan Kebijakan Formulasi Terhadap Undang-Undang Nomor 16 Tahun 2011 Tentang Bantuan Hukum". Jurnal Hukum Prioritas, Vol. 4 No. 22014. Jakarta: Faculty of Law Trisakti;

Sandefur, Rebecca L. "Lawyers' Pro Bono Service and America - Style Civil Legal Assistance." Law \& Society Review. Vol. 41 No. 1. 2007. South America: John Wiley \& Sons publications;

Satriawan, Andan Adi. Upik Hamidah. and Satria Prayoga. "Implementasi Bantuan Hukum Pada Masyarakat Miskin di Kota Bandar Lampung (Studi Di Lembaga Bantuan Hukum Bandar Lampung)". Jurnal HIMA 
HAN, Vol. 1 No. 2. 2014. Lampung: Faculty of Law Universitas Lampung;

Setia, Hekki Purnama. "Faktor-Faktor Yang Menjadi Kendala dalam Pemberian Bantuan Hukum Secara Cuma-Cuma (Prodeo) dalam Perkara Pidana di Pengadilan Negeri di Samarinda". Jurnal Ilmu Hukum dan Sosial, Vol. 2 No. 1. 2014. Samarinda: Faculty of Law Universitas Tujuh Belas Agustus;

Sihombing, Eka NAM. "Mendorong Pembentukan Peraturan daerah Tentang Bantuan Hukum di Provinsi Sumatera Utara". Jurnal Rechtsvinding: Media Pembinaan Hukum Nasional, Vol. 2 No. 1. April 2013. Jakarta: BP$\mathrm{HN}$;

Soekanto, Soerjono. 1986. Faktor-Faktor yang Mempengaruhi Penegakan Hukum. Jakarta: Rajawali Press;

Suroto. "Macam-Macam Konsep Negara Hukum". Jurnal Konstitus, Vol. I No. 1. November 2012. Jakarta: Mahkamah Konstitusi;

Utari, Bq Ishariatym Wika. "Bantuan Hukum Secara Cuma-Cuma Bagi Tersangka/Terdakwa Yang Tidak Mampu." Jurnal IUS, Vol. 2. No. 4 Year 2014. Mataram: Faculty of Law Universitas Mataram;

Wijayanta, Tata. "Study Bantuan Hukum Golongan Tidak Mampu dalam Perkara Perdata di Pengadilan Negeri Yogyakarta." Jurnal Mimbar Hukum, Vol. 24. No. 1. 2012. Yogyakarta: Faculty of Law UGM;

Wirawan, Cynthia. Syafruddin Kalo. and Edi Yunara. "Implementasi Pemberian Bantuan Hukum Cuma-Cuma (Pro Bono Publico) dalam Perkara Pidana di Kota Medan Ditinjau Berdasarkan Undang-Undang Nomor 16 Tahun 2011 Tentang Bantuan Hukum (Studi di Lembaga Bantuan Hukum Medan)." Jurnal Mahupiki, Vol. 2. No. 1. 2014. Medan: Faculty of Law Universitas Sumatera Utara. 